\title{
Exosomes for gene therapy effectively inhibit the endothelial-mesenchymal transition in mouse aortic endothelial cells
}

\author{
Zhenyuan Wei ${ }^{\dagger}$, Yang Zhao ${ }^{\dagger}$, Peichun Hsu, Shang Guo, Chi Zhang and Biao Zhong ${ }^{*}$
}

\begin{abstract}
Background: Heterotopic ossification $(\mathrm{HO})$ can limit joint activity, causes ankylosis and impairs the function and rehabilitation of patients. Endothelial to mesenchymal transition (EndMT) plays an important role in the pathogenesis of HO, and high expression of SMAD7(Mothers Against Decapentaplegic Homolog 7) in endothelial cells can effectively reverse the TGF- $\beta 1$ mediated EndMT. This article studied an appropriately engineered exosome with high biocompatibility and good targeting property to administrate SMAD7 gene therapy to inhibit the EndMT.

Methods: Exosomes from mouse aortic endothelial cells were cultured and harvested. DSPE-PEG and antibody CD34 were combined to exosomes to synthesize the endothelial cell targeting exosome vector (Exosome-DSPE-PEGAbCD34). The biocompatibility, stability, targeting and cell internalization of exosome vector were tested, then the Exosome-DSPE-PEG-AbCD34 was loaded with Smad7 plasmid and administrated to MAECs to examine its therapeutic effect on EndMT of MAEC mediated by TGF- $\beta 1$.
\end{abstract}

Results: The Exosome-DSPE-PEG-AbCD34 has no impact on MAEC cell viability at high concentration, and exosomeDSPE-PEG-Ab $\mathrm{CD}_{\mathrm{C} 34}$ could be stably stored at $4^{\circ} \mathrm{C}$ and $37^{\circ} \mathrm{C}$ for at least 8 days. Exosome-DSPE-PEG-Ab $\mathrm{CD}_{34}$ has better targeting property to MAEC cells and can enter into the cells more effectively. The Exosome-DSPE-PEG-Ab $\mathrm{CD}_{34}-\mathrm{Smad7}$ could significantly increase the level of SMAD7, decrease the expression of TGF- $\beta 1$, and effectively reverse the EndMT of MAEC mediated by TGF- $\beta 1$ in MAEC cells.

Conclusions: The synthesized Exosome-DSPE-PEG-AbCD34-Smad7 has good biological properties and can effectively reverse the EndMT of MAEC mediated by TGF- $\beta 1$. Thus, Exosome-DSPE-PEG-AbCD34-Smad7 may has the potential for the prevention and treatment of $\mathrm{HO}$.

Keywords: Gene therapy, SMAD7, exosome, endothelial-mesenchymal transition, mouse aortic endothelial cells, endothelial cell targeting property

\section{Background}

Heterotopic ossification $(\mathrm{HO})$ is an abnormal process of bone formation that occurs in muscle or connective

${ }^{*}$ Correspondence: biao.zhong@sjtu.edu.cn

†Zhenyuan Wei and Yang Zhao contributed equally to this work and should be considered as co-first authors.

Department of Orthopedic Surgery, and Shanghai Institute

of Microsurgery on Extremities, Shanghai Jiao Tong University Affiliated

Sixth People's Hospital, Shanghai 200233, China tissue [1]. HO can lead to pain, decrease in the range of motion of adjacent joints, peripheral nerve compression, and pressure ulcers. $\mathrm{HO}$ also has a high morbidity rate, ranging from $10 \%$ to $36 \%$. These factors make it become one of complications affecting the functional rehabilitation of elbow and hip fracture patients. Therefore, identifying methods to prevent and reverse the pathological process of $\mathrm{HO}$ has great economic and social value [2]. Previous studies have shown that progenitor cells in local soft tissue affected by inflammation niches and signaling original author(s) and the source, provide a link to the Creative Commons licence, and indicate if changes were made. The images or other third party material in this article are included in the article's Creative Commons licence, unless indicated otherwise in a credit line to the material. If material is not included in the article's Creative Commons licence and your intended use is not permitted by statutory regulation or exceeds the permitted use, you will need to obtain permission directly from the copyright holder. To view a copy of this licence, visit http://creativecommons.org/licenses/by/4.0/. The Creative Commons Public Domain Dedication waiver (http://creativeco mmons.org/publicdomain/zero/1.0/) applies to the data made available in this article, unless otherwise stated in a credit line to the data. 
pathways gradually differentiate into chondrocyte phenotype and osteoblast phenotype and finally form mature bone tissue to produce ectopic bone [3]. However, the pathological mechanisms and related signaling pathways of $\mathrm{HO}$ are still unclear $[4,5]$, and its prevention and treatment methods are limited.

Recent studies have shown that the endothelial mesenchymal transition (EndMT) pathway is important in the pathogenesis of $\mathrm{HO}[6,7]$. Endothelial markers were reported to be expressed in chondrocytes and osteocytes in ectopic bone of an $\mathrm{HO}$ animal model, which were different from normal osteocytes and chondrocytes, indicating that endothelial cells are associated with the occurrence and development of $\mathrm{HO}[8,9]$. Lounev et al. also proved that the stimulation of inflammatory mediators and signals in local tissue induce vascular endothelial cells transform into chondrocytes and osteocytes through the EndMT pathway, and form ectopic ossification via intramembrane osteogenesis and chondrogenic osteogenesis [10]. Therefore, EndMT can be used as a target to develop prevention and treatment methods for HO. There are a plenty of studies have found that the transcription products of Smad7 gene can competitively bind to type II TGF- $\beta$ receptor, thus inhibiting the TGF- $\beta$ signaling pathway and playing a negative regulatory role [11]. Our previous finding also indicated that SMAD7 overexpression in vascular endothelial cells can effectively block the TGF- $\beta$ mediated EndMT signaling pathway and thereby attenuate HO. However, SMAD7 overexpression in vascular endothelial cells requires gene vectors with high biocompatibility, good sustainedrelease performance, high plasmid loading and good targeting properties. Lentiviral vector is a widely used gene vector, but it is difficult to use in clinical treatment due to the limitations of its targeting properties and biosafety.

Exosomes, a sort of saccular vesicles with a diameter of 30-150 nm secreted by living cells, are important mediators of "material exchange" as well as information transmission between cells $[12,13]$. As a natural endogenous substance transporter, exosomes have the advantages of low toxicity, no immunogenicity and good permeability and are thus superior carriers for effective molecule delivery $[14,15]$. At present, exosomes have been successfully loaded with small molecule such as drugs, miRNAs, genes and proteins for the treatment of cancer, Alzheimer's disease and other diseases [16-21]. Endothelial cells are now one of the most popular cell sources of exosomes due to their high purity and productivity, ease of availability, and lack of ethical issues. Exosomes produced by the endothelial cells share the similar marker molecules with progenitor cells and contribute to the physiological functions of endothelium as well as the pathogenesis of cardiovascular disease. Thus we selected exosomes derived from mouse aortic endothelial cells as the vehicles of gene therapy $[12,22]$.

In this study, we bound the DSPE-PEG-AbCD34 (antibody of CD34) to the surface of secretory exosomes to synthesize exosome gene vector (Exosome-DSPE-PEGAbCD34) with high endothelial cell targeting property. Then we loaded the Smad7 plasmid into the Exo-DSPEPEG-AbCD34 and examined its effect on the TGF- $\beta$ mediated EndMT pathway. Our study thus provides a new approach for the clinical prevention and treatment of $\mathrm{HO}$.

\section{Materials and Methods \\ Cell culture}

Mouse aortic endothelial cells (MAEC) were purchased from ATCC. The cells were cultured in DMEM medium containing $10 \% \mathrm{FBS}$ and $5 \% \mathrm{CO}_{2}$ at $37^{\circ} \mathrm{C}$. When the cell density reached $85 \%$, the cells were digested with trypsin solution and passaged.

\section{Exosome isolation}

The exosomes of MAEC were extracted using the Invitrogen $^{\mathrm{TM}}$ Total Exosome Isolation kit according to the manufacturer's instructions. Briefly, $1 \mathrm{ml}$ of cell-free culture media was mixed with $500 \mu \mathrm{l}$ Exosome Isolation reagent and incubated at $4^{\circ} \mathrm{C}$ for overnight. The mixed solution was centrifuged at $10,000 \times \mathrm{g}$ for 1 hour, supernatant was discarded and exosome pellets were resuspended for the following experiments.

\section{Preparation of Exo-DSPE-PEG-Ab ${ }_{\mathrm{CD} 34}$}

As exosome membrane, mainly composed of lipid membrane, is rich in cholesterol, sphingomyelin and ganglioside, liposoluble compounds are therefore easy to be integrated into exosome membrane [23]. DSPE-PEG$\mathrm{Ab}_{\mathrm{CD} 34}$ was synthesized by conjugating $\mathrm{CD} 34$ antibody to DSPE-PEG2000-NHS. Then the exosomes were treated with DSPE-PEG-Ab $\mathrm{Cb}_{\mathrm{C} 34}$. The lipophilic DSPE was fused into the exosome membrane, meanwhile the PEG-Ab ${ }_{\mathrm{CD} 34}$ was carried to the exosome surface. The procedures were as follows: firstly, DSPE-PEG- $\mathrm{Ab}_{\mathrm{CD} 34}$ was synthesized by the reaction of DSPE-PEG2000-NHS with excessive $\mathrm{Ab}_{\mathrm{CD} 34}$ at room temperature for 24 hours. Then the prepared exosomes were dispersed in PBS, and the exosome protein content was adjusted to $50 \mathrm{mg} / \mathrm{ml} .0 .1 \mathrm{~mL}$ DSPEPEG-Ab $\mathrm{CD}_{\mathrm{CD} 3}$ solution with a concentration of $20 \mathrm{mg} / \mathrm{mL}$ was added to $2 \mathrm{ml}$ of exosome dispersion, then the mixture was gently blown and incubated at room temperature for 1 hour. After that, the dispersion solution was transferred into a special centrifuge tube and ultracentrifuged at $120,000 \mathrm{~g}$ and $4{ }^{\circ} \mathrm{C}$ for $70 \mathrm{~min}$. The upper solution was sucked away and the unbound DSPE-PEG-Ab ${ }_{\mathrm{CD} 34}$ 
was removed. The precipitate obtained was Exo-DSPEPEG-Ab $\mathrm{C}_{\mathrm{CD} 34}$ connected with $\mathrm{Ab}_{\mathrm{CD} 34}$. The precooled PBS solution was added to the precipitate to blow and dissolve again for standby.

\section{Transmission electron microscope (TEM) detection}

The purity and structural integrity of exosomes were determined by transmission electron microscopy (TEM), With the following procedure: The protein content of exosome dispersion was diluted to $100 \mathrm{mg} / \mathrm{ml}$ with HEPES buffer, then $10 \mathrm{uL}$ exosome dispersion was added to 200 mesh copper mesh (covered with carbon film) for transmission electron microscopy, and the copper mesh was placed in a desiccator at room temperature until completely dried. Then samples were observed under the accelerated voltage of $75 \mathrm{kV}$, and photos were taken at the same time.

\section{Detection of exosome particle size}

First, the protein content of exosome dispersion was adjusted to $50 \mathrm{mg} / \mathrm{mL}$, and $20 \mathrm{uL}$ of exosome dispersion was added to $980 \mathrm{uL}$ high $\mathrm{ddH} 2 \mathrm{O}$, then the particle size of exosome was measured by a potential particle size analyzer, based on a light scattering method.

\section{CCK-8 assay}

The concentration of logarithmic phase cells was adjusted to $5 \times 10^{4}$ cells $/ \mathrm{ml}$. $100 \mathrm{uL}$ cell suspension was added into each well of a 96 well culture plate, and incubated in 5\% $\mathrm{CO}_{2}$ incubator at $37^{\circ} \mathrm{C}$ for $24 \mathrm{~h}$. After drug treatment, the supernatant was discarded, and $100 \mathrm{uL}$ of fresh medium was added to each well, followed by $10 \mathrm{uL}$ of CCK- 8 solution. After 4 hours of culture at $37^{\circ} \mathrm{C}$, the absorbance (OD) value of each well at $450 \mathrm{~nm}$ was detected by an enzyme reader.

The cell viability rate was calculated by the formula: Cell viability $\%=(\mathrm{OD}$ sample - OD blank) / (OD control - OD blank) $\times 100$.

\section{Laser confocal microscopy detection}

The cells were seeded in 96 well plates at the initial density of $1 \times 10^{5}$ cells per well. The cells were incubated with Exosome-DSPE-PEG-Ab $\mathrm{CD}_{\mathrm{C} 34}$ at $37^{\circ} \mathrm{C}$ for $2 \mathrm{~h}$, then cultured in $60 \mathrm{~nm}$ lysotracker red medium at $37^{\circ} \mathrm{C}$ for 30 min, washed three times with cold PBS, and fixed with $4 \%$ paraformaldehyde for $20 \mathrm{~min}$. Then, cells were treated with DAPI for $10 \mathrm{~min}$ and washed twice with PBS. The cells were observed by confocal laser scanning microscope (Olympus FluoView fv-1000, Olympus optics Co., Ltd., Tokyo, Japan) and observed with imaging software. The number of FITC positive cells in 10 visual fields in each group was counted, and the mean fluorescence of FITC intensity was calculated by use of imageJ 2.0.

\section{qPCR assay}

The total RNA was extracted using the Trizol (Invitrogen) kit according to the manufacturer's instructions, then the mRNA was reversely transcribed into cDNA according to the manufacturer's instructions of the TaqMan microRNA reverse transcription kit. The expression of each gene was detected using Applied Biosystems 7500 fluorescence quantitative PCR. The primers used were provided by SANGON Biotech (Shanghai) Co., Ltd. The primers designed in this paper are shown in Table 1.

\section{SDS-PAGE gel electrophoresis and Western Blot}

SDS-PAGE gel electrophoresis was used to detect $\mathrm{Ab}_{\mathrm{CD} 34}$ on Exosome-DSPE-PEG-Ab $\mathrm{C}_{\mathrm{CD} 34}$, then an appropriate amount of RIPA cell lysate was added to the precipitate of exosome after $12,000 \mathrm{~g}$ centrifugation and then incubated in an ice bath for $25 \mathrm{~min}$. It was then centrifuged at $10,000 \mathrm{~g}$ for $20 \mathrm{~min}$. The BCA protein quantitative kit was used to quantify the protein concentration of exosomes and cell lysates. The lysate containing the same amount of protein was mixed with the SDS-PAGE sample loading buffer, heated to $100^{\circ} \mathrm{C}$ and kept for $5 \mathrm{~min}$. The protein in the above mixture was separated by SDS-PAGE electrophoresis, then stained with R250 gel dyeing solution, and then decolorized with the decolorizing solution. The exosome marker

Table 1 The qPCR primers used in manuscript

\begin{tabular}{|c|c|c|}
\hline Genes & Forward Primer ( $5^{\prime}$ to $\left.3^{\prime}\right)$ & Reverse Primer ( $5^{\prime}$ to $\left.3^{\prime}\right)$ \\
\hline $\begin{array}{l}\text { Smad7 } \\
\text { CD31 }\end{array}$ & $\begin{array}{l}\text { 5'-CCCGGCGGCGAGGACGAGGAG-3' } \\
\text { 5'-GGAGGTGACAGAAGGTGGGATTG-3' }\end{array}$ & $\begin{array}{l}\text { 5'-GGATGGTGGTGACCTTTGGCAC-3' } \\
\text { 5'-GCTTGGCAGCGAAACACTAACAGG-3' }\end{array}$ \\
\hline VE-cadherin & 5'-CTTCACCCAGACCAAGTACACA-3' & 5'-AATGGTGAAAGCGTCCTGGT-3' \\
\hline $\mathrm{N}$-cadherin & 5'-GTGCCATTAGCCAAGGGAATTCAGC-3' & 5'-GCGTTCCTGTTCCACTCATAGGAGG-3' \\
\hline Vimentin & 5'-GGACCAGCTAACCAACGACA-3' & 5'-AAGGTCAAGACGTGCCAGAG-3' \\
\hline Gapdh & 5'-AGTGCCAGCCTCGTCTCATA-3' & 5'-GAGAAGGCAGCCCTGGTAAC-3' \\
\hline
\end{tabular}


proteins (CD9, CD63) [24], SMAD7, CD31, VE-cadherin, N-cadherin, vimentin and GAPDH were detected by western blot assay. Exosomes and cells were lysed by RIPA lysate, and after $12,000 \mathrm{~g}$ centrifugation, the protein of exosomes and cell lysate was quantified using the BCA protein quantitative kit. The lysate containing the same amount of protein was mixed with the loading buffer to prepare samples. The protein samples were separated by SDS-PAGE and analyzed by western blot, then the protein was transferred to PVDF membrane by blot, and then sealed with 5\% skim milk for 1 hour at room temperature. The first antibody corresponding to the detected protein was added and incubated at $4^{\circ} \mathrm{C}$ for 4 hours. After reacting with HRP labeled secondary antibody and washing, ECL luminous solution was used for exposure and photo recording.

\section{Data analysis and statistical methods}

Statistical data were expressed as mean $\pm \mathrm{SD}$, and oneway analysis of variance (ANOVA) was used for statistical analysis. ${ }^{*} P<0.05, * * P<0.01$ and $* P<0.001$ were regarded as significant differences. SPSS 18.0 software was used for statistical analysis.

\section{Results \\ Preparation and characterization of Exosome-DSPE-PEG-AbCD34}

Exosomes can be used as natural endogenous material carriers, and exosomes loaded with drugs have the advantages of low toxicity, no immunogenicity and good permeability. In this study, we first isolated exosomes from the MAEC culture medium of mouse aortic endothelial cells, and then synthesized Exosome-DSPE-PEG-Ab ${ }_{\mathrm{CD} 34}$ by inserting the synthesized DSPE-PEG- $\mathrm{Ab}_{\mathrm{CD} 34}$ into the exosome membrane structure. The exosomes were characterized by TEM (Fig. 1A) and potential particle size analyzer (Fig. 1B), the average diameter of prepared

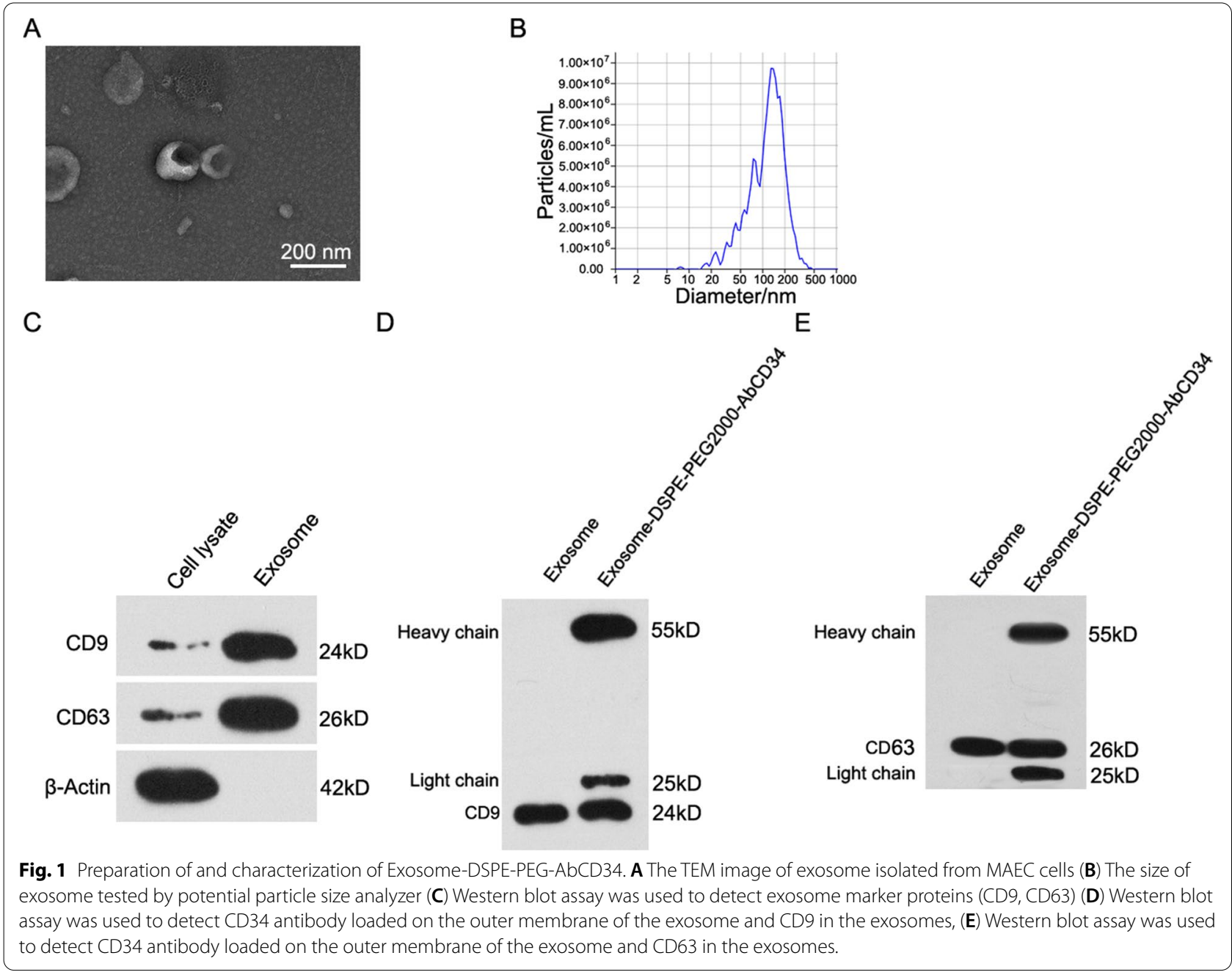


exosomes was about $150 \mathrm{~nm}$. Western blot assay was used to detect exosome marker proteins (CD9, CD36) (Fig. 1C), as showed in the result, with CD9 and CD36 can be tested in exosome, meaning that the exosome was successfully extracted. CD34 antibody, which loaded on the outer membrane of the exosome, was detected by western blot assay, too (Fig. 1D, E). And the heavy chain and light chain of antibody was only showed in the exosome-DSPE-PEG-AbCD34. These results showed that we had successfully isolated and extracted MAEC exosomes from mouse aortic endothelial cells, and synthesized Exosome-DSPE-PEG-AbCD34 with CD34 targeting property.

\section{Biocompatibility, stability, targeting property and cell internalization of Exosome-DSPE-PEG-Ab $\mathrm{CD}_{\mathrm{CD} 4}$}

Biocompatibility, stability, targeting and cell internalization are important characteristics of gene carriers. We used the CCK- 8 assay to detect the effect of different concentrations of Exosome-DSPE-PEG-Ab $\mathrm{CD}_{\mathrm{CD} 34}$ on the viability of MAEC cells. The results showed that treatment with the concentration from 10 to $320 \mathrm{ug} / \mathrm{ml}$ of Exosome-DSPE-PEG- $\mathrm{Ab}_{\mathrm{CD} 34}$ had a negligible effect on cell proliferation and viability of MAEC cells (Fig. 2A). Then we tested the stability of Exosome-DSPE-PEG$\mathrm{Ab}_{\mathrm{CD} 34}$ at $4^{\circ} \mathrm{C}$ and $37^{\circ} \mathrm{C}$ by DLS and western blot assay (Fig. 2B, C). Results showed that after being stored at $4^{\circ} \mathrm{C}$ and $37^{\circ} \mathrm{C}$ for 8 days, the particle size of exosome-DSPEPEG-AbCD34 could stably maintained at around 140 $\mathrm{nm}$, which means the Exosome-DSPE-PEG-AbCD34 can be stably stored at $4^{\circ} \mathrm{C}$ and $37^{\circ} \mathrm{C}$ for at least 8 days. Then we observed the targeting effect of exosome-DSPE-PEG$\mathrm{Ab}_{\mathrm{CD} 34}$ on MAEC cells by laser confocal microscopy. The results showed that more FITC labeled exosome-DSPEPEG- $A b_{C D 34}$ could be observed on the surface and inside of MAEC cells after the exosome vector and cells were incubated for 48 hours, which indicates that exosomeDSPE-PEG-Ab $\mathrm{CD}_{\mathrm{C} 34}$ has better cell targeting performance and cell internalization than exosome-DSPE-PEG (Figure 2D).

\section{Synthesis of Exosome-DSPE-PEG-Ab $\mathrm{CD}_{\mathrm{CD}}$-Smad7 and its effect on SMAD7 expression in MAEC cells}

We incubated the Smad7 plasmid with Exosome-DSPEPEG-AbCD34 to synthesize Exosome-DSPE-PEG$\mathrm{Ab}_{\mathrm{CD} 34^{-}}-\operatorname{Smad7}$, and then DNA gel electrophoresis was used to detect the loading of pcDNA3.1-Smad7 in the
Exosome-DSPE-PEG-Ab $\mathrm{CD}_{44^{-}} \operatorname{Smad7}$ (Figure 3A). The result showed that pcDNA3.1- Smad7 can be loaded in the exosome, Exosome-DSPE-PEG and Exosome-DSPEPEG-AbCD34. After exosome-DSPE-PEG-Ab ${ }_{\mathrm{CD} 34^{-}}$ Smad7 was co-cultured with MAEC cells for $48 \mathrm{~h}$, the gene level of SMAD7 in MAEC cells was detected by qPCR and western blot. The results showed that Exosome-DSPE-PEG-Ab $\mathrm{CD}_{\mathrm{C} 34}$ could transport pcDNA3.1Smad7 into MAEC cells and overexpress SMAD7 successfully (Figure 3B, C and D).

\section{The effect of Exosome-DSPE-PEG-Ab $\mathrm{CD}_{4}$-Smad7 on EndMT pathway in MAEC cells}

The EndMT has been proved to be an important mechanism in the pathogenesis of HO. In its molecular pathophysiological mechanism, the TGF- $\beta$ (transforming growth factor- $\beta$ ) superfamily signaling pathway plays a leading role, and Smad7 is an important suppressor gene in this signaling pathway. To determine the inhibiting effect of Exosome-DSPE-PEG-AbCD34-SMAD7 on the EndMT of MAECS, we stimulated MAECS with $10 \mathrm{ng} / \mathrm{ml} \mathrm{TGF}-\beta 1$ for $48 \mathrm{~h}$ to simulate the effect of TGF$\beta 1$ on local EndMT at the cellular level with or without the administration of Exosome-DSPE-PEG-AbCD34Smad7. The effect of Exosome-DSPE-PEG-Ab ${ }_{\mathrm{CD} 34^{-}}$ Smad7 on MAECS was detected by qPCR and western blot. The results showed that TGF- $\beta 1$ could downregulate CD31 and VE-cadherin, and up regulate $\mathrm{N}$-cadherin and vimentin. Compared with the control group, the Exosome-DSPE-PEG-Ab $\mathrm{CD}_{\mathrm{C} 34}-\mathrm{Smad} 7$ transfection group could apparently decrease the level of TGF- $\beta 1$ in MAECs. Furthermore, the Exosome-DSPE-PEG-AbCD34-Smad7 can upregulate the expression of CD31 and VE-cadherin. Meanwhile, it also downregulated the expression of N-cadherin and vimentin (Figure $4 \mathrm{C}$ and $\mathrm{D}$ ), which means it can then counteract the effect of TGF- $\beta 1$ induced EndMT in MAECs. In conclusion, the overexpression of the SMAD7 induced by Exosome-DSPEPEG-Ab $\mathrm{CD}_{\mathrm{C} 4}-\mathrm{Smad} 7$ can effectively reverse the EndMT pathway of MAECS mediated by TGF- $\beta 1$.

\section{Discussion}

Heterotopic ossification $(\mathrm{HO})$ refers to the formation of atypical bone in muscle or at other sites of connective tissue, and $\mathrm{HO}$ which occurs around joints will develop clinical symptoms [25-27]. As a pathological bone formation, HO has an incidence rate vary from $9 \%-90 \%$,

(See figure on next page.)

Fig. 2 Biocompatibility, stability, targeting property and cell internalization of Exosome-DSPE-PEG-AbCD34. A Biocompatibility of Exosome-DSPE-PEG-AbCD34 to MAEC cells was tested by CCK-8 assay; $\mathbf{B}$ Stability of Exosome-DSPE-PEG-AbCD34 at $4{ }^{\circ} \mathrm{C}$ and $37^{\circ} \mathrm{C}$ in different time; $\mathbf{C}$ western blot assay was used to detected the level of CD9 and CD36 at $4^{\circ} \mathrm{C}$ and $37^{\circ} \mathrm{C}$ in different time; D Confocal microscopy images of cell internalization testing of Exosome-DSPE-PEG-AbCD34 at $\times 20$ magnification. The bar plot below shows the number of FITC positive cells and the calculated mean fluorescence of FITC intensity of each group. Scale bars: $2 \mu \mathrm{m}$. 
A

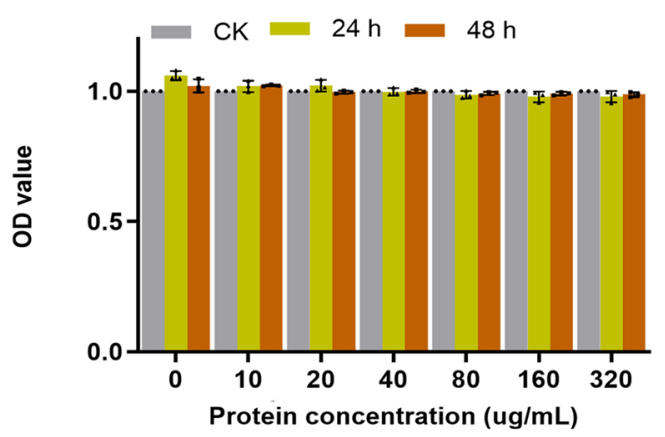

C

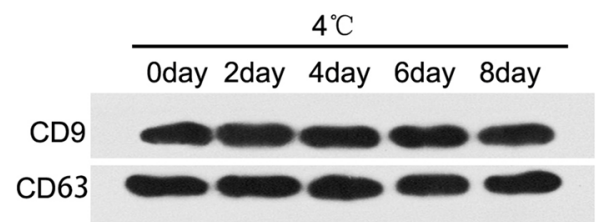

D

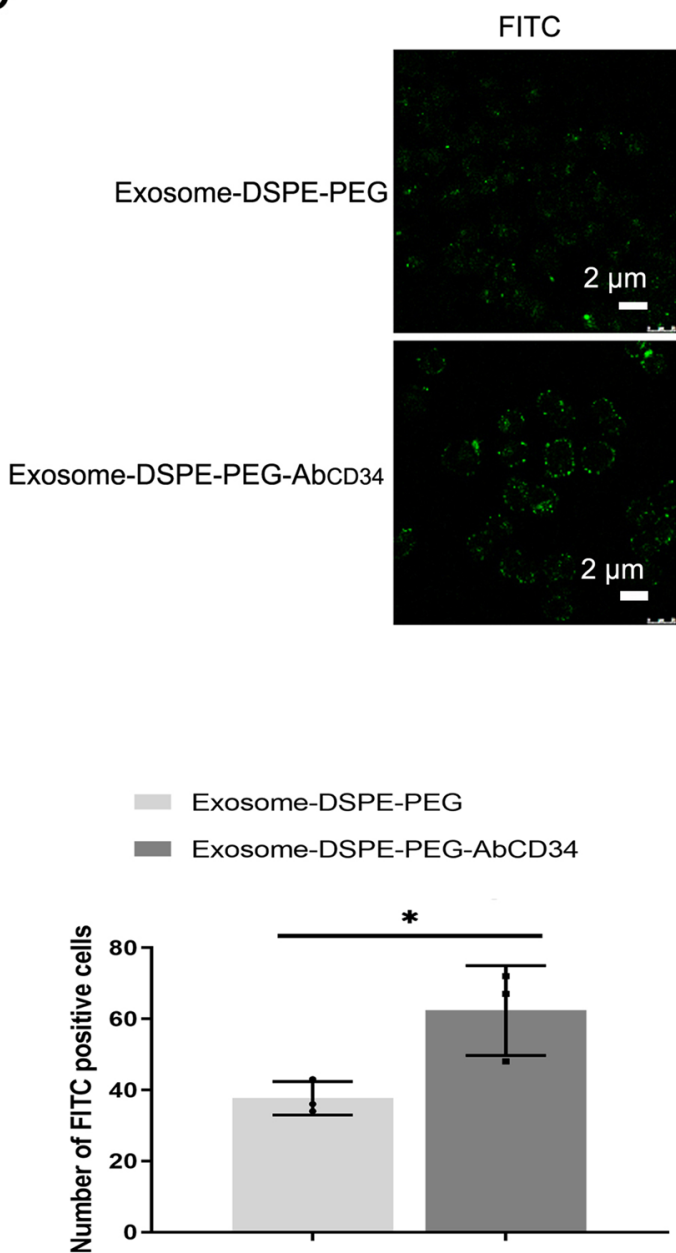

B
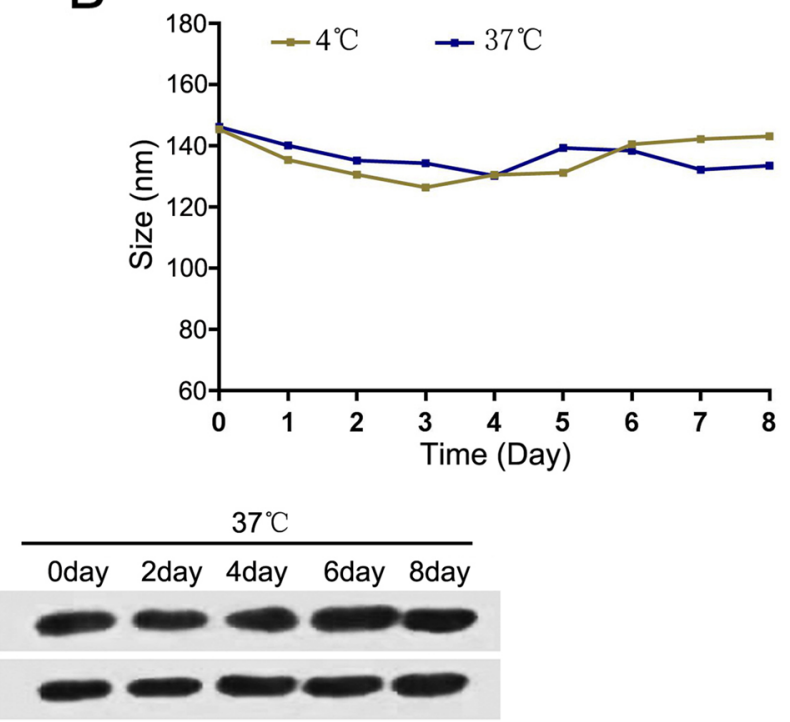

Lysotracker Red

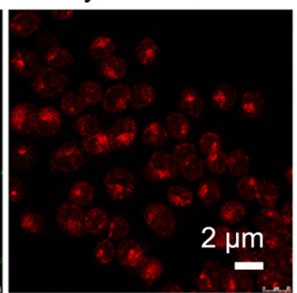

DAPI
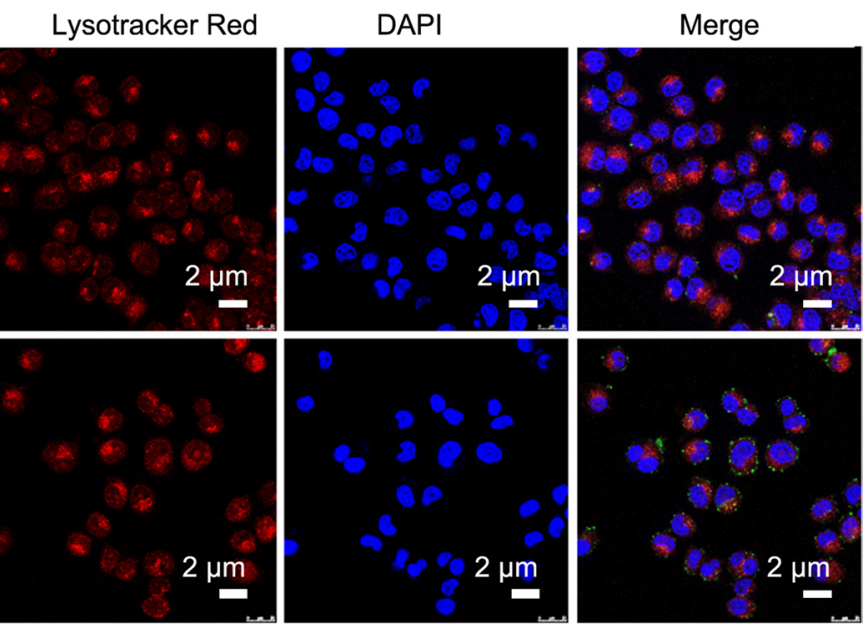

Exosome-DSPE-PEG

Exosome-DSPE-PEG-AbCD34

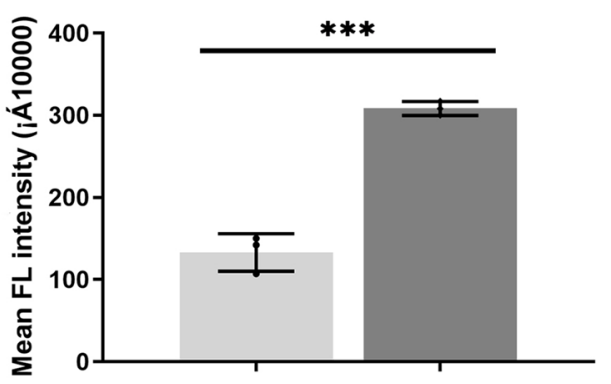

Fig. 2 (See legend on previous page.) 


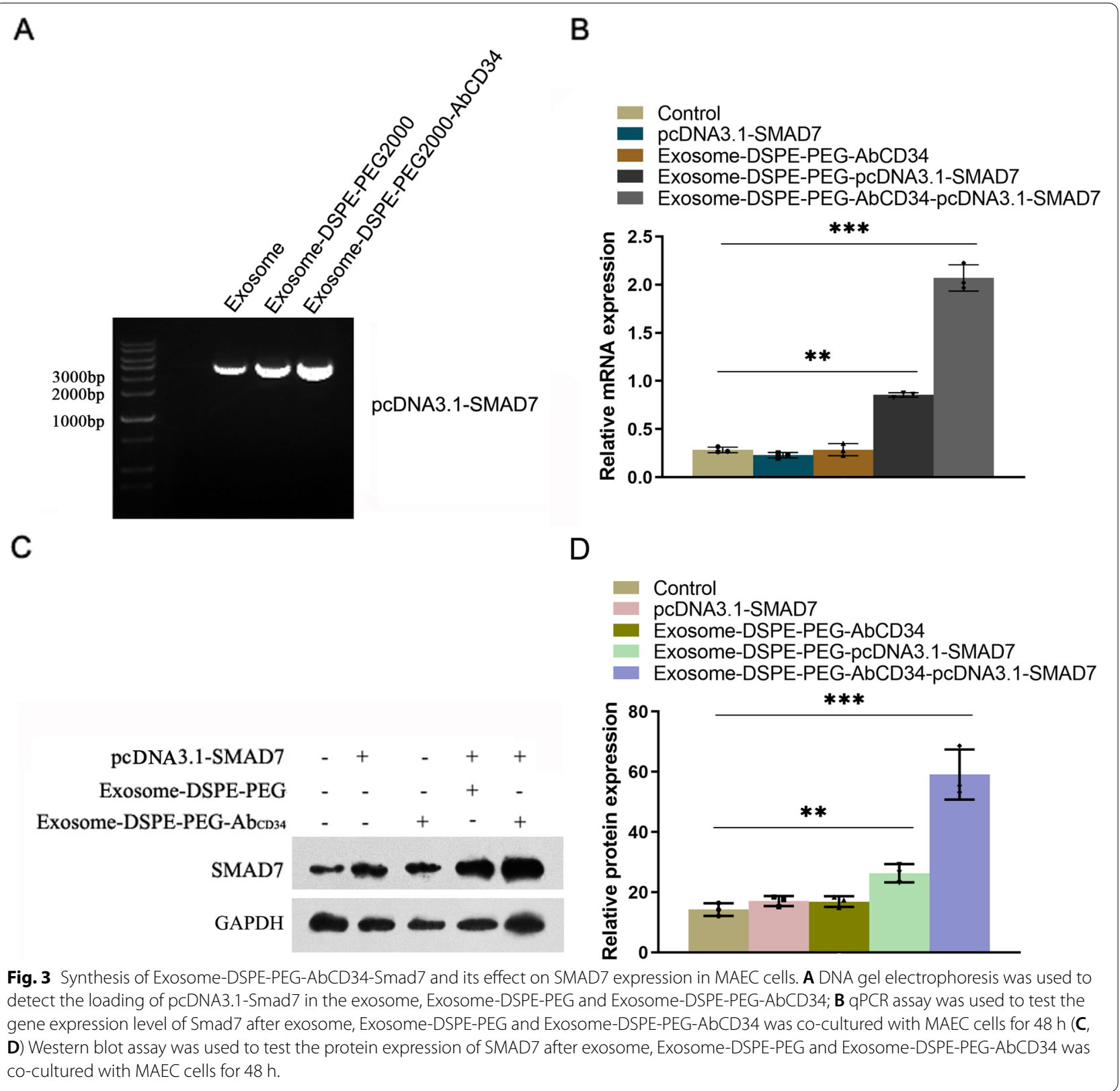

and it can be influenced by several risk factors [4]. Severe HO can limit joint activity, even causing ankylosis and loss of joint function. It can also cause neurological symptoms and local pressure ulcers due to nerve wrapping [28]. Dyspareunia caused by heterotopic ossification of the adductor longus is also a rare complication [29]. Dynamic histomorphometry showed that compared with normal bone, ectopic ossified bone had higher metabolic activity, increased bone deposition rate, wider bone suture, and larger number of osteoblasts [30]. The fate of progenitor cells such as mesenchymal stem cells can be affected by stimulation from microenvironment [31, 32], and it has been proved that progenitor cells, inflammation niches and disorder of signaling pathway promote the formation of HO. Based on previous studies of $\mathrm{HO}$ related molecular mechanism and signaling pathway, we studied the targeted gene therapy method that may be used for the treatment of HO.

There were a plenty of studies indicating that the endothelial to mesenchymal transition (EndMT) plays an important role in the pathogenesis of HO. Under the regulation of inflammatory factors and the local neuroendocrine system, vascular endothelial cells pass through the 


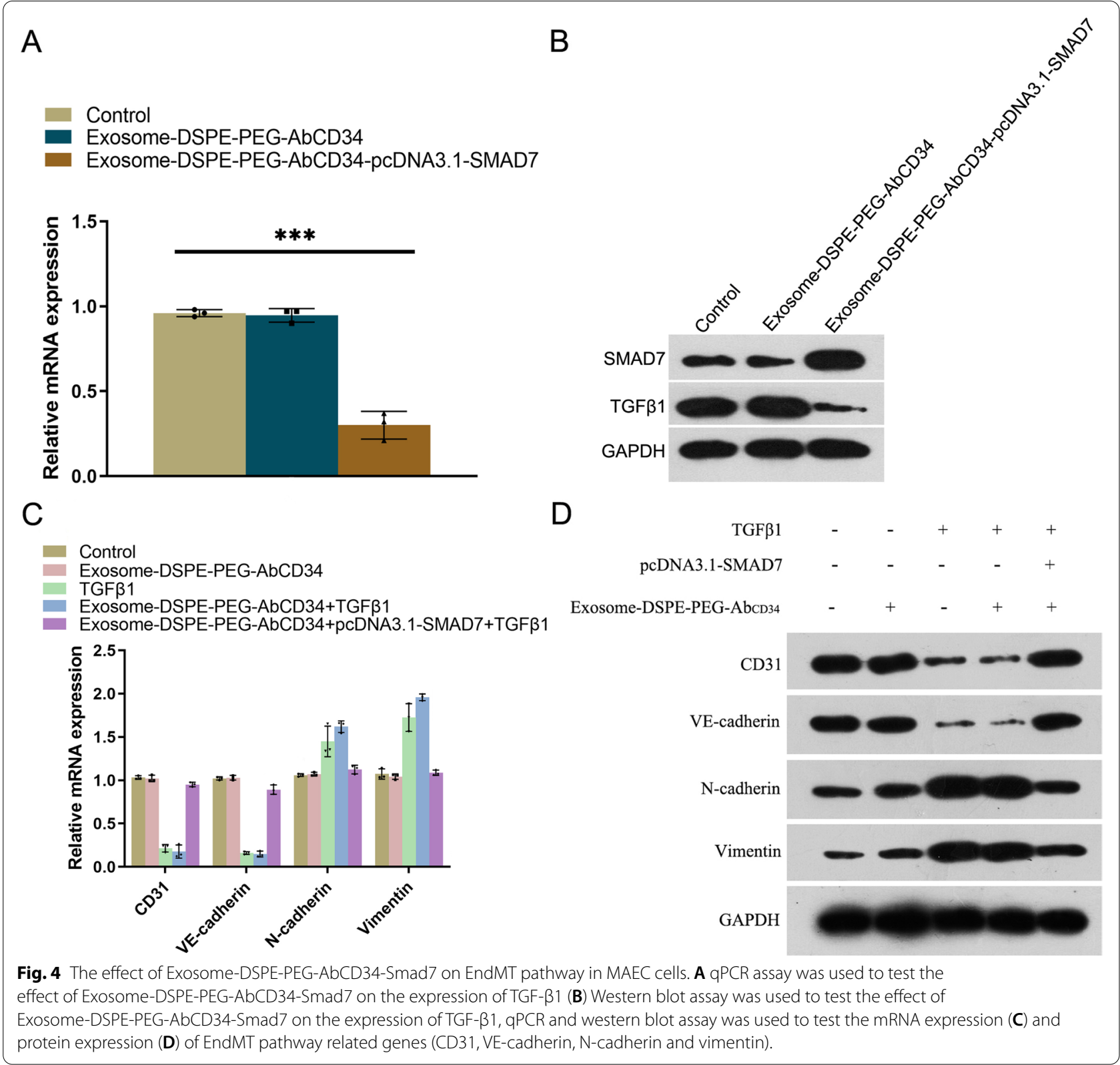

vascular barrier, dissociate into tissues, and dedifferentiate into mesenchymal stem cells, then differentiate into chondrocytes and osteocytes under local conditions, and form $\mathrm{HO}$ tissue through the process of intramembrane osteogenesis and chondrogenic osteogenesis. EndMT was mainly induced by the TGF- $\beta$ superfamily signaling pathway, and SMAD7 is an important suppressor gene of the TGF- $\beta$ signaling pathway. Previous studies have shown that SMAD7 has the potential to prevent myofibroblast transformation and other EndMT progression, which verifies that high expression of SMAD7 in endothelial cells can effectively reverse the TGF- $\beta 1$ mediated EndMT pathway of RAOECS. This result indicates that SMAD7 can be used in the prevention and treatment of HO [7]. The Smad7 gene needs the help of a gene vector with high biocompatibility and good targeting property to enter into the cells. Exosomes are small vesicles with a diameter of 30-150 nm naturally secreted by cells [33], and they can be used as potential carriers to deliver drugs, therapeutic genes or proteins in clinical treatment due to their stability and high biocompatibility [34-37]. In current study, the exosomes produced from mouse aortic endothelial cells were selected as vehicles of gene therapy as it mirror the marker molecules of 
parent cells and was associated with many physiological progresses such as anti-inflammation, anti-oxidation and the inhibition of endothelial-to-mesenchymal transition (EndMT) [12, 22]. However, normal exosomes cannot target specific cells. Loading targeted peptides with amphiphilic groups on the surface of exosomes can improve the targeting of exosomes.

The hydrophilic peptides always need to be modified by liposoluble compounds to integrate into the hydrophobic membrane of exosomes, which are mainly composed of lipid membrane. In this study, we used DSPE-PEG2000NHS to bind CD34 antibody (AbCD34) to the surface of secreted exosomes to synthesize an exosome vector with a high endothelial cell targeting property (ExosomeDSPE-PEG-AbCD34). The assays we performed to detect its physical and biological characteristics showed that Exosome-DSPE-PEG-AbCD34 had no effect on MAEC cell viability at a high concentration, and ExosomeDSPE-PEG-AbCD34 could be stably stored at $4^{\circ} \mathrm{C}$ as well as room temperature for at least 8 days. Moreover, compared with Exosome-DSPE-PEG, Exosome-DSPEPEG-AbCD34 has a better targeting property to MAEC cells and can enter into endothelial cells more effectively, which confirmed that the modification with antibody CD34 can remarkably develop exosomes' ability to internalize into endothelial cells. Then we loaded $\operatorname{Smad} 7$ plasmid into the Exosome-DSPE-PEG-AbCD34 to compose the Exosome-DSPE-PEG-Ab ${ }_{\mathrm{CD} 34^{-}}-\operatorname{Smad} 7$, and the transfection assay showed that Exosome-DSPE-PEG-Ab ${ }_{\mathrm{CD} 34^{-}}$ Smad7 could significantly increase the level of SMAD7 in MAEC cells.

Finally, we examined the effect of Exosome-DSPEPEG- $\mathrm{Ab}_{\mathrm{CD} 34}-\mathrm{Smad} 7$ on the molecules related to the EndMT pathway in MAEC cells. The results showed that the Exosome-DSPE-PEG-Ab $\mathrm{CD}_{\mathrm{C} 34}$-Smad7 transfection group can up regulate the expression of CD31 and VE-cadherin, which proved that the Exosome-DSPEPEG-AbCD34-Smad7 can counteract the effect of TGF$\beta 1$. Meanwhile, Exosome-DSPE-PEG-Ab $\mathrm{CD} 34^{-} \mathrm{Smad} 7$ transfection also downregulated the expression of N-cadherin and vimentin.

\section{Conclusions}

In conclusion, the overexpression of SMAD7 induced by Exosome-DSPE-PEG-Ab $\mathrm{CD}_{\mathrm{CD}}{ }^{-} \mathrm{Smad}$ can effectively reverse the EndMT pathway of MAEC mediated by TGF- $\beta 1$. These results indicate that Exosome-DSPEPEG-AbCD34-Smad7 may has the potential for the prevention and treatment of HO. This study provides a theoretical basis and gene therapy strategy for the prevention and treatment of $\mathrm{HO}$. Whether this modified method may be suitable for other sort of exosome and the concrete effect of Exosome-DSPE-PEG-AbCD34$S m a d 7$ on prevention of HO progression should be studied in further research.

\section{Abbreviations}

HO: Heterotopic ossification; EndMT: Endothelial to mesenchymal transition; SMAD7: Mothers Against Decapentaplegic Homolog 7; MAECs: Mouse aortic endothelial cells; TEM: Transmission electron microscopy.

\section{Supplementary Information}

The online version contains supplementary material available at https://doi. org/10.1186/s12891-021-04896-0.

Additional file 1.

\section{Acknowledgements}

Not applicable.

\section{Conflicts of interest}

The authors declared no potential conflicts of interest with respect to the research, authorship, and publication of this article.

\section{Authors' contributions}

ZYW and YZ planned and executed experiments and wrote the manuscript, PCH composed figures and analyzed results, SG and CZ critically reviewed the manuscript, BZ oversaw the project, critically reviewed and edited the manuscript. All authors have read and approved the manuscript.

\section{Funding}

This work was supported by the National Natural Science Foundation of China [grant number 81772426], this funding was used to pay for costs associated with cell and reagents purchase; The Program of Science and Technology Commission of Shanghai [grant number 15dz2353800], this funding was used to pay for costs covering the use of instruments such as laser confocal microscopy; and the Shanghai Jiao Tong University Affiliated Sixth People's Hospital's own funds [grant number LYZY-0262], this funding was used to pay the fee of experiment technicians. All of funding bodies will not assist with study design, data interpretation and manuscript writing.

\section{Availability of data and materials}

The datasets generated and/or analyzed during the current study are available from the corresponding author by reasonable request.

\section{Declarations}

Ethics approval and consent to participate Not applicable.

Consent for publication Not applicable.

\section{Competing interests}

The authors declare that they have no competing interests.

Received: 9 August 2021 Accepted: 15 November 2021 Published online: 30 November 2021

\section{References}

1. Zhang C, Zhong B, Luo C. Treatment strategy of terrible triad of the elbow: experience in Shanghai 6th People's Hospital. Injury. 2014;45(6):942-8.

2. Brown K, Dharm-Datta S, Potter B, Etherington J, Mistlin A, Hsu J, et al. Comparison of development of heterotopic ossification in injured US and 
UK Armed Services personnel with combat-related amputations: preliminary findings and hypotheses regarding causality. J Trauma. 2010;69 Suppl 1:S116-22.

3. Meyers C, Lisiecki J, Miller S, Levin A, Fayad L, Ding C, et al. Heterotopic Ossification: A Comprehensive Review. JBMR Plus. 2019;3(4):e10172.

4. van Kuijk A, Geurts A, van Kuppevelt H. Neurogenic heterotopic ossification in spinal cord injury. Spinal Cord. 2002:40(7):313-26.

5. Lin F, Wang N, Zhang T. The role of endothelial-mesenchymal transition in development and pathological process. IUBMB Life. 2012:64(9):717-23.

6. Medici D, Olsen B. The role of endothelial-mesenchymal transition in heterotopic ossification. J Bone Miner Res. 2012;27(8):1619-22.

7. Zhang C, Zhang Y, Zhong B, Luo C. SMAD7 prevents heterotopic ossification in a rat Achilles tendon injury model via regulation of endothelialmesenchymal transition. FEBS J. 2016;283(7):1275-85.

8. Medici D, Shore E, Lounev V, Kaplan F, Kalluri R, Olsen B. Conversion of vascular endothelial cells into multipotent stem-like cells. Nat Med. 2010;16(12):1400-6.

9. Shui Y, Lv G, Shan L, Fan C, Tian N, Zhang L, et al. Epimedin C Promotes Vascularization during BMP2-Induced Osteogenesis and Tumor-Associated Angiogenesis. Am J Chin Med. 2017:45(5):1093-111.

10. Lounev V, Ramachandran R, Wosczyna M, Yamamoto M, Maidment A, Shore $E$, et al. Identification of progenitor cells that contribute to heterotopic skeletogenesis. J Bone Joint Surg Am. 2009;91(3):652-63.

11. Hua C, Wang Z, Zhang J, Peng X, Hou X, Yang Y, et al. SMAD7, an antagonist of TGF-beta signaling, is a candidate of prenatal skeletal muscle development and weaning weight in pigs. Mol Biol Rep. 2016:43(4):241-51.

12. Zeng CY, Xu J, Liu X, Lu YQ. Cardioprotective Roles of Endothelial Progenitor Cell-Derived Exosomes. Front Cardiovasc Med. 2021:8:717536.

13. Salimi L, Akbari A, Jabbari N, Mojarad B, Vahhabi A, Szafert S, et al. Synergies in exosomes and autophagy pathways for cellular homeostasis and metastasis of tumor cells. Cell Biosci. 2020;10:64.

14. Nikfarjam S, Rezaie J, Kashanchi F, Jafari R. Dexosomes as a cell-free vaccine for cancer immunotherapy. J Exp Clin Cancer Res. 2020;39(1):258.

15. Nikfarjam S, Rezaie J, Zolbanin NM, Jafari R. Mesenchymal stem cell derived-exosomes: a modern approach in translational medicine. J Transl Med. 2020;18(1):449.

16. Elewaily M, Elsergany A. Emerging role of exosomes and exosomal microRNA in cancer: pathophysiology and clinical potential. J Cancer Res Clin Oncol. 2021;147(3):637-48.

17. Yuan F, Zhou Z. Exosomes derived from Taxol-resistant nasopharyngeal carcinoma (NPC) cells transferred DDX53 to NPC cells and promoted cancer resistance to Taxol. Eur Rev Med Pharmacol Sci. 2021;25(1):127-38.

18. Jena B, Mandal M. The emerging roles of exosomes in anti-cancer drug resistance and tumor progression: An insight towards tumormicroenvironment interaction. Biochim Biophys Acta Rev Cancer. 2021;1875(1):188488

19. Malm T, Loppi S, Kanninen K. Exosomes in Alzheimer's disease. Neurochem Int. 2016;97:193-9.

20. Liu R, Liu J, Ji X, Liu Y. Synthetic nucleic acids delivered by exosomes: a potential therapeutic for generelated metabolic brain diseases. Metab Brain Dis. 2013;28(4):551-62.

21. Alvarez-Erviti L, Seow Y, Yin H, Betts C, Lakhal S, Wood M. Delivery of siRNA to the mouse brain by systemic injection of targeted exosomes. Nat Biotechnol. 2011;29(4):341-5.

22. Mathiesen A, Hamilton T, Carter N, Brown M, McPheat W, Dobrian A Endothelial extracellular vesicles: from keepers of health to messengers of disease. Int J Mol Sci. 2021;22(9):4640.

23. Zhan R, Leng X, Liu X, Wang X, Gong J, Yan L, et al. Heat shock protein 70 is secreted from endothelial cells by a non-classical pathway involving exosomes. Biochem Biophys Res Commun. 2009;387(2):229-33.

24. Kumar D, Gupta D, Shankar S, Srivastava R. Biomolecular characterization of exosomes released from cancer stem cells: Possible implications for biomarker and treatment of cancer. Oncotarget. 2015;6(5):3280-91.

25. Eggli S, Woo A. Risk factors for heterotopic ossification in total hip arthroplasty. Arch Orthop Trauma Surg. 2001:121(9):531-5.

26. Sirin E, Okay E, Khalilov T, Turkoz K, Erol B, Tetik C. Heterotopic ossification on the volar surface of the distal radius in a child with fibrodysplasia ossificans progressiva: challenges in surgical excision of a rare condition. Hand Surg Rehabil. 2021;40(2):194-7.
27. Endo T, Imagama S, Kato S, Kaito T, Sakai H, Ikegawa S, et al. Association between vitamin A intake and disease severity in early-onset heterotopic ossification of the posterior longitudinal ligament of the spine. Glob Spine J. 2021;2192568221989300.

28. Brooke M, Heard D, de Lateur B, Moeller D, Alquist A. Heterotopic ossification and peripheral nerve entrapment: early diagnosis and excision. Arch Phys Med Rehabil. 1991;72(6):425-9.

29. Russell G, Perry M, Pearsall A. Heterotopic ossification of the adductor longus muscle presenting as dyspareunia. Am J Orthop (Belle Mead, NJ). 2000;29(11):879-82

30. Wilkinson J, Stockley I, Hamer A, Barrington N, Eastell R. Biochemical markers of bone turnover and development of heterotopic ossification after total hip arthroplasty. J Orthop Res. 2003;21(3):529-34.

31. Rezaie J, Mehranjani MS, Rahbarghazi R, Shariatzadeh MA. Angiogenic and Restorative Abilities of Human Mesenchymal Stem Cells Were Reduced Following Treatment With Serum From Diabetes Mellitus Type 2 Patients. J Cell Biochem. 2018;119(1):524-35.

32. Heidarzadeh M, Keyhanmanesh R, Rezabakhsh A, Rahbarghazi R, Rezaie J, Saberianpour S, et al. Chronic asthmatic condition modulated the onset of aging in bone marrow mesenchymal stem cells. Cell Biochem Funct. 2021;39(6):821-7

33. Sheller-Miller S, Choi K, Choi C, Menon R. Cyclic-recombinase-reporter mouse model to determine exosome communication and function during pregnancy. Am J Obstet Gynecol. 2019;221(5):502.e501-12.

34. Wang X, Tai Z, Tian J, Zhang W, Yao C, Zhang L, et al. Reducible chimeric polypeptide consisting of octa-D-arginine and tetra-L-histidine peptides as an efficient gene delivery vector. Int J Nanomedicine. 2015;10:4669-90.

35. Wang Y, Zhang Q, Yang G, Wei Y, Li M, Du E, et al. RPE-derived exosomes rescue the photoreceptors during retina degeneration: an intraocular approach to deliver exosomes into the subretinal space. Drug Deliv. 2021;28(1):218-28.

36. Sahoo S, Kariya T, Ishikawa K. Targeted delivery of therapeutic agents to the heart. Nat Rev Cardiol. 2021;18(6):389-99.

37. Rezaei R, Baghaei K, Amani D, Piccin A, Hashemi S, Asadzadeh Aghdaei $\mathrm{H}$, et al. Exosome-mediated delivery of functionally active miRNA-375-3p mimic regulate epithelial mesenchymal transition (EMT) of colon cancer cells. Life Sci. 2021;269:119035.

\section{Publisher's Note}

Springer Nature remains neutral with regard to jurisdictional claims in published maps and institutional affiliations.
Ready to submit your research? Choose BMC and benefit from:

- fast, convenient online submission

- thorough peer review by experienced researchers in your field

- rapid publication on acceptance

- support for research data, including large and complex data types

- gold Open Access which fosters wider collaboration and increased citations

- maximum visibility for your research: over 100M website views per year

At BMC, research is always in progress.

Learn more biomedcentral.com/submissions 